CATALAN REVIEW

Catalan Review

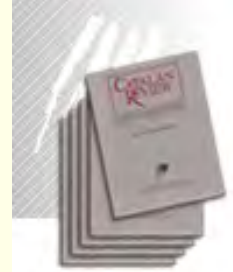

You are accessing the Digital Archive of the Catalan Review Journal.

By accessing and/or using this Digital Archive, you accept and agree to abide by the Terms and Conditions of Use available at http://www.nacs-

catalanstudies.org/catalan review.html

Catalan Review is the premier international scholarly journal devoted to all aspects of Catalan culture. By Catalan culture is understood all manifestations of intellectual and artistic life produced in the Catalan language or in the geographical areas where Catalan is spoken. Catalan Review has been in publication since 1986 .
NORTH

AMERICAN

CATALAN

SOCIETY
Esteu accedint a l'Arxiu Digital del Catalan Review

A l' accedir i / o utilitzar aquest Arxiu Digital, vostè accepta i es compromet a complir els termes i condicions d'ús disponibles a http://www.nacs-

catalanstudies.org/catalan review.html

Catalan Review és la primera revista internacional dedicada a tots els aspectes de la cultura catalana. Per la cultura catalana s'entén totes les manifestacions de la vida intel lectual i artística produïda en llengua catalana o en les zones geogràfiques on es parla català. Catalan Review es publica des de 1986.

\title{
Desire at the Kiosk: Publicity and Barcelona in the 1930s Jordana Mendelson
}

Catalan Review, Vol. XVIII, number 1-2, (1998), p. 191-207 


\title{
DESIRE AT THE KIOSK: PUBLICITY AND BARCELONA IN THE I93os
}

\author{
JORDANA MENDELSON
}

\section{ABSTRACT}

Publicity in Barcelona during the r93os generated some remarkable examples of visual modernity that at the same time function as indicators of a widespread cultural practice motivated by the intersection of applied psychology and photographic experimentation. One of the foremost theoreticians and practitioners of the use of photography in advertising was Pere Català-Pic, who through his involvement with the Generalitat's Institut Psicotècnic was also a leader in the rationalization and teaching of publicity. This essay examines Català-Pic's work in the light of his critical writings on the phototechnician and his central role in the transformation of commercial publicity into political propaganda during the Civil War, a process that drew upon the debates of the previous decade and that is illuminated through the study of Català-Pic's public and priyate correspondence with Pedro Prat-Gaballí.

$\mathrm{B}$ arcelona is a city on display. Its architecture, exhibition history, and famed artists make it one of the most brilliant demonstration pieces of conspicuous modernity. While marketing that modernity became a central issue for artists and industrialists alike from the late nineteenth century onwards, it was during the 1930 s that a particularly highpitched discussion about publicity as a motivator of economic, artistic, and technical progress took place. In reading the literature from this period and by studying some of the artists who practiced and theorized publicity as their main occupation, one gleans a sense of the points of agreement and contestation that emerged among Barcelona's growing class of artist-technicians. Thinking about publicity in terms of the language and debates that it generated means not just looking at images, but also understanding the role that these images played in creating a culture of promotion that was grounded in the visual. At the same time, in Barcelona the idea of advertising and the development of it as a profession (requiring specialized knowledge) implicated a range of institutional practices, from the regular publication of articles and books to the organization of conferences, seminars, and associations. This paper will survey the leading figures and events in the history of publicity in Barcelona during the rg3os. While by no means compre- 
hensive, it is meant to introduce the importance of mass culture in retelling-and re-imagining-the ways in which the arts and industry combined to transform the kiosk, where the work of publicity artists was put on display for admiration, criticism, and purchase, into a location of competing ambitions for both economic prosperity and, at times, political revolution.

\section{Organizations, Manuals, and Treatises}

Understanding the development of publicity in Barcelona requires entering a space in which training and pedagogy commingled with criticism and politics. From the outset, one sees that competition emerged as a key both to emerging economies in the city as well as to the position of individuals within government-sponsored and private organizations. Given the relatively large number of articles and books that appeared in the 1930 , it is possible to reconstruct some of this history, even if the stakes involved in refining the differences, for example, between "avant-garde," "rational," and "psycho-technical" publicity may be more difficult to grasp from our contemporary viewpoint.

Pedro Prat-Gaballí was one of the earliest advertisers to write on the topic of publicity in Barcelona. He founded magazines devoted to the business of advertising like Comercio (1913) and Fama: Revista Técnica para Anunciantes, Directores de Publicidad y Jefes de Ventas (1919-2I), and wrote for another later magazine that also dealt with similar issues and practices, Actividad (1925-31). All three were published in Barcelona and contributed to developing a dialogue about publicity in the city and, in the nation as a whole. As a leading theoretician, editor, and active professional in the field, Prat-Gaballi taught a course on the subject of publicity from $1915^{-16}$ for the Barcelona Chamber of Commerce. Published in 1917 as Una Nueva Técnica: La Publicidad Cientifica, his course book outlined the need to push knowledge about the discipline from "chance" to "method." The standardization and communication of best practices through pedagogy and print media were vital tools both for the production of publicity and its distribution.

Charting the relationship between the present state of advertising and the developments of the previous century, Prat-Gaballif fixed on the year 1895 as a turning point, explaining that the definition of publicity that emerged at that time was still relevant in the nineteen-teens:

la publicidad es la ciencia que enseña a conocer el espíritu del público y a aplicar este conocimiento a los medios de que disponen la imaginación y el inge- 
nio para dar noticia al mayor número posible de individuos de la utilidad o las ventajas de un artículo, en forma que ejerza una acción eficaz, es decir, que llegue a sugerir deseos y a determinar actos de voluntad. (14)

Essentially, the purpose of publicity was to connect product with consumer through the activation of the consumer's desire for the usefulness of the object or idea. Prat-Gaballí and others believed that this process could be analyzed, taught, and reproduced. Many of the sources quoted in La Publicidad Cientifica were foreign, with PratGaballí acknowledging (as many would) that Spain lagged behind other countries in its development of strategic publicity. It was the accidental state of publicity, according to the author, that prevented the full realization of modern commercial culture in Spain.

In addition to providing a justification for the development of publicity in the country, Prat-Gaballi wrote his books to function as manuals. He detailed the advantages and disadvantages of different modes of display and communication media. He drew from international and national examples; his writing is clear, and the structure of his book organized logically to move from general theories to specific problems. As training manuals, his book and others provide insight into the apparent demand for publications that would convert the interested amateur into a skilled professional. From his experience as director of his own advertising companies, Prat-Gaballí was keenly aware of the need to build enterprises that would draw on existing clients, as well as cultivating others. As the business grew, so would the need for trained assistants.

Although Prat-Gaballi lived in Madrid from 1928-35, he continued throughout these years to make his presence felt in Barcelona among younger technicians and in the context of new initiatives. In his 1934 book Publicidad Racional, Prat-Gaballi recounted the struggle to create a professional culture around publicity in Spain. He told the story from a position of earned authority, a position to which he would refer in his later publications of the post-war period as well. Throughout the I93os he operated as a liaison between the publicity groups that developed in Barcelona and in Madrid, both through the circulation of his publications and his leadership role in conferences and organizations. He maintained a strong reputation in both cities. $\mathrm{He}$ was the first President and later Honorary President of the Barcelona Publi-Club, which was formed in 1927 (Prat-Gaballi, Publicidad Racional 8), and contributed the opening article to the first number of the Club's magazine Publi-Graf, also in 1934. It was during this time that Prat-Gaballí began to distinguish his own work in publicity from that of orhers actively participating in the newly established Seminari de Publicitat del Institut Psicotècnic de la Generalitat in Barcelona and 
its Butlleti. His involvement with the Catalan establishment as it was developing during the Second Republic accounts for the fact that in his 1934 book he emphasized the necessary role of the "técnico publicitario," who, as he explained, "ha de poseer las dotes imaginativas del literato, la facultad de análasis del psicólogo y el temperamento práctico del comerciante" (13). In this passage, Prat-Gaballí marked his proximity to the work being done in Barcelona by emphasizing two main ideas, both of which had been present in his earlier work and to which he called particular attention in Publicidad Racional: the interaction of psychology and scientific analysis in designing publicity and the need for technicians to be cultured individuals with a broad literary orientation.

In balancing the literary with the psychological and commercial, Prat-Gaballi may have been influenced by one of his most vibrant (and prolific) interlocutors, the Catalan photographer Pere CatalàPic, whose essay of March 23, 1933 on "La publicitat moderna" in Mirador triggered a public and private correspondence between the two. In his article, Català-Pic promoted the work of the newly formed Institut Psicotècnic and made a forceful argument for the necessary use of psychology to understand and plan publicity. Without knowledge of psychology, Català-Pic argued, the work of the technician would be improvised, accidental, and inefficient. Psychology, in orher words, was supposed to provide a system for rationalizing and predicting the outcome of a publicity campaign even before it was enacted. He also made a strong declaration that, with the establishment of the Institut Psicotècnic, "la publicitat obre en nostre país una nova etapa." It was to Català-Pic's description of the Institute's activities as "new" that Prat-Gaballi voiced his objections in his essay, "Els Serveis de Psicotècnica Publicitaria de la Generalitat de Catalunya," published in L'Opinió on April 6, 1933. What was new for Català-Pic, Prat-Gaballí complained, had an over twenty-year history in Barcelona. Citing his own 1916 course for the Barcelona Chamber of Commerce, Prat-Gaballí took umbrage at Català-Pic's claim to have brought innovarive ideas to the public's attention, for he saw them as reiterative of the previously published literature. He was also quick to criticize the appointment of Alexandre Chleusebairgue to the Institute, observing "com és el nostre poble, un nom estranger sempre dóna a les coses molt més prestigi que un nom català." Throughout his subsequent editorials and private correspondence with Català-Pic, Prat-Gaballi continued to find fault with Chelusebairgue, despite

I. I thank Pilar Parcerisas for her generosity in sharing with me her archive of materials ond and by Català-Pic, especially his correspondence with Prat-Gaballí. I also thank Brad Epps for his careful reading and editing of an earlier version of this text. 
offering general support for the Institute's goals and despite expressing his gratitude to Català-Pic for his generosity and professionalism.

For his part, Català-Pic responded with a second article, again titled "La publicitat moderna," published in Mirador on April 20, 1933. Here he addressed Prat-Gaballi's criticisms and professed his admiration for the older generation of publicity technicians. $\mathrm{He}$ described Prat-Gaballí as "el nostre professor," even though the two had never met and acknowledged that he learned his earliest lessons about publicity from books like Una Nueva Técnica: La Publicidad Cientifica. Nonetheless, he carefully differentiated these earlier endeavors from the new work proposed by the Institute, which Català-Pic argued was "una ciència ben nostra, investigada, controlada i anotada a casa nostra amb gent nostra $\mathrm{i}$ amb els aparells del nostre laboratori." After explaining the value of understanding human psychology for provoking the most direct and intense response to publicity, Català-Pic clarified the difference between Prat-Gaballi's theories and those of the Institute:

la psicotècnia que ens proposem és d'un ordre purament científic, en el qual el cartell sigui la conseqüència d'unes condicions psicològiques determinades, i per tant apte per estimular els òrgans sensitivo-motors de l'individu. Heus ací, doncs, resumida la diferència entre el concepte dels publicitaris moderns a l'avantguarda dels quals va el senyor Prat Gaballí, i la del grup novíssim que constituïm el Seminari de la Publicitat.

For those participating in the Institute, publicity had become a question of biology, a matter of studying the motor-sensory responses to the visual and auditory cues delivered by modern designers who used science to predict responses even before drafting their advertisements.

The Institute was part of a longer history of psychiatry and psychology in Barcelona. Dr. Emili Mira i López, who directed the Institute, was one of the foremost authorities on psychiatry in Spain during the early twentieth century. In 1926, he published El psicoanàlisi and in 1935 a Manual de Psiquiatria. In 1933, he became the first professor of psychiatry in Spain when he was elected to the position at the Universitat Autònoma in Barcelona. With the declaration of the Second Republic, Mira i López expanded the mission of the Institut d'Orientació Professional and renamed it the Institut Psicotècnic de la Generalitat de Catalunya. Under this new banner, Mira i López dedicated a section of the Institute's work to "psicotècnica comercial e industrial" (Sáiz 225). Alexandre Chleusebairgue was named the director and Rafael Bori the section's secretary.

Bori, like several of the Institute's other members, had a long 
publishing history in Barcelona. Despite Prat-Gaballís complaints both in the press and to Català-Pic personally about the Institute, he and Bori had both served on the board of the Asociacion de Profesionales en Publicidad, also known as the Publi-Club, along with José Gardó and Juan Aubeyzon. Bori and Gardó published together a two volume Manual Práctico de Publicidad in 1926-28 [Fig. I], and both contributed actively to Actividad and Fama. In 1936, Bori and Gardó published a new and expanded edition of their Manual, the size of which attests to the growth in the field of publicity as well as the

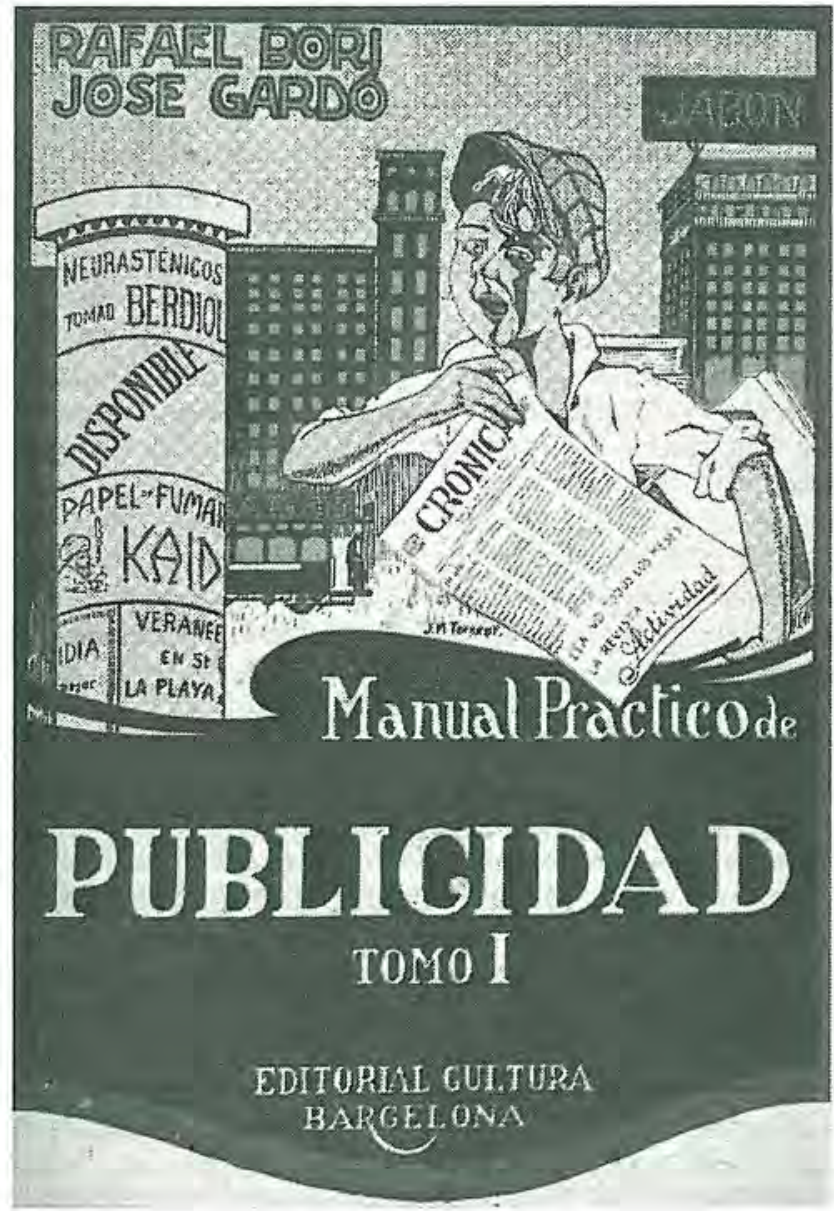

FIGURA 1 
demand for comprehensive literature on the topic: their pocket size paperback two-volume edition of the mid-19zos had become a massive, hardback door-stopper titled Tratado completo de publicidad $y$ propaganda. While not exactly the same book, the Tratado drew on many of the lessons laid out for readers in the earlier Manual. What was significantly different was that the Tratado contained a new section, approximately thirty-pages in length, on "Psicologia," which was absent from the publications of the 1920s. A central activity of the Institute was pedagogy, and the first number of the Butlleti remarked that the first class offered had an enrollment of forty students. With the increasing numbers of students, and the expanding role of the scientific study of publicity in relation to economic modernity, those involved with the Institute launched a number of initiatives, motivated no doubt by the reformist climate of the Second Republic.

Català-Pic advocated for the Institute, as we have seen, and participated actively in the Institute's mission. Alexandre Chleusebairgue was one of his teachers, and Català-Pic's articles in Mirador demonstrated that he had taken to heart the importance of psychology in the creation of a new era in Catalan publicity. He played a key role too in mediating between his Barcelona-based colleagues and PratGaballi, who became increasingly disillusioned with the Institute and its Butlletí. During the planning for the 1934 Congrés Internacional de la Publicitat, Prat-Gaballí voiced complaints about the Publi-Club and was critical of the Institute's members, in particular Rafael Bori, whom he accused of grandstanding at the Congress. As Prat-Gaballi recounted to Català-Pic in his letters, there was a breakdown between the Catalan Publi-Club and the Madrid delegates at the Congress. Given the difficulties in coordinating the Congress and his dissatisfaction with the Publi-Club, Prat-Gaballí began to distance himself from the Catalan group's work. Although the debates within this community of publicity technicians is too complex to outline here, it is nonetheless important to signal that the Barcelona group was creating an identity for itself that was perceived to be separate from that of those working outside of Catalunya. Prat-Gaballí complained in a January 10, 1934 letter to Català-Pic that the articles published in the Butlleti offered nothing new, and were merely "word plays" that made a farce out of the Institute's scientific claims. ${ }^{2}$ Finally, in a letter dated March 19, 1935, Prat-Gaballi wrote to Català-Pic expressing his desire to step down as Honorary President of Publi-Club. 


\section{Català-Pic as Photo-Technician}

Reading the letters from Prat-Gaballí to Català-Pic provide a window into the personal investments and debates that characterized the establishment of the Institut Psicotècnica and its impact on publicity in Spain. Català-Pic's work evinces, however, an enthusiastic embrace of the role of the technician in the production of publicity. $\mathrm{He}$ developed for himself a solid foundation from which to theorize the relationship of photography to psychology in publicity. For Català-Pic, artistic and technical innovations, when paired with knowledge about psychology, could be put to use in productive ways for the good of the nation. As utopian as such a position may sound in retrospect,

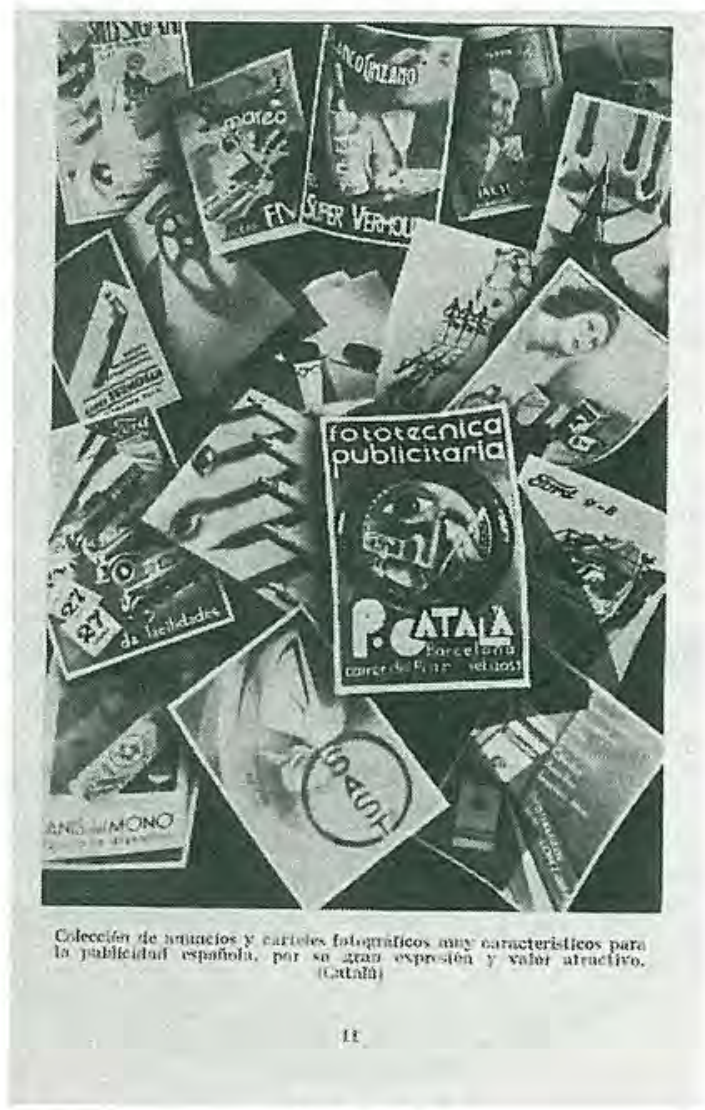

FIGURA 2 
Català-Pic's writings clearly articulated a role for photography in this process.

Català-Pic's involvement with the Institute began almost immediately with its founding. He attended Alexandre Chleusebairgue's course on "Psicotècnia de la Publicitat" in 1932-33, and gave two courses himself at the Institute: in 1934-35, a course titled "La Publicitat Moderna" and in $1935-36$ another one, titled "La psicologia com a base de la publicitat i de les vendes." Català-Pic actively published in the Institute's Butlleti, advocated for the Institute in the local press, and published additional texts on modern photography and publicity in national publications like Revista Ford. His publicity designs were reproduced in Fritz Giese's Psicotecnia, which was translated from German to Castilian with a prologue by the Institute's director Emili Mira i López in 1933 [Fig. 2]. Giese lectured in Madrid and Barcelona in 1932, and it is possible that he saw Català-Pic's work. A more likely scenario, however, was that Mira i López chose the illustrations for the translated edition and, by including Català-Pic, cemented the relationship between the photographer (his designs and writings) and the Institute.

In addition to his work at the Institute, Català-Pic was one of the founders of Publi-Cinema, a movie theater on the Passeig de Gràcia that began publishing a magazine of the same name in October 1934. From the start, its organizers saw Publi-Cinema as an extension of the Publi-Club and as yet another means of bringing general attention to the role of publicity in Barcelona. For example, on the occasion of the I Saló Nacional de Fotografia Publicitària, held at the Publi-Club in April of 1932, Català-Pic gave a lecture titled "La fotografia moderna com a element de publicitat." Spectacle and print media blended in the work of the Publi-Club, enabling Català-Pic to test his ideas about the expanded role of the photo-technician as a participant in the transformation of the city's commerce into a socially and economically progressive culture.

In making a place for photography in publicity, Català-Pic differentiated the role of the photo-technician from that of the studio photographer, and he did so at the same time that he made this transition himself. From I915 to I931, Català-Pic worked as a portrait photographer in Valls. When he moved back to Barcelona, he dedicated himself to a different kind of photographic practice. He announced the change in, among other places, the magazine Art de la Llum, which was published by the Agrupació Fotogràfica de Barcelona, an association that supported pictorialist photography and was largely composed of amateur photographers. In the opening pages of the August 1933 issue, Català-Pic detailed the difference between his previous work and his current interests, and produced 
something like a manifesto in favor of the technician, who should be "capaç de veure l'objecte amb la màxima intensitat, de comprendre'n la íntima expressió, la seva significació, en relació a l'espai, a l'ambient, a l'atmòsfera, la seva possibilitat de promoure [una] actitud psíquica" (20). For Català-Pic, the photo-technician had to have greater cultural awareness and tighter connections to society than the studio photographer: "El veritable fototècnic publicitari ha d'unir al coneixement de la tècnica fotogràfica una gran cultura general i artística, una gran sensibilitat receptiva i una força de representació expressiva, uns grans coneixements de les lleis psicotècniques, psicològiques i una forta intuició i una lògica seleccionadora dels elements a emprar" (20).

To mark his re-entry into the Barcelona photographic scene, Català-Pic distanced himself from his previous profession as a studio photographer. He correlated this professional move with a geographic move from the "camp de Tarragona" to the metropolitan and economic concerns of the city. With his new practice, he acquired the technical and cultural knowledge capable of transforming the camera, in its relationship to reality, into a mechanism for guiding viewer's (and future consumer's) habits and desires. His articles in the Seminari's Butlleti outlined in practical terms what this transformation required from photographers. According to Català-Pic, photo-technicians should embrace, more than anything else, the specific characteristics of the new vision that the camera facilitated for its users. Close-ups, distortion, and abstraction were all qualities that the technician should exploit in publicity - and all were qualities built into the camera's eye. From the "visió d'insecte," as he wrote in his "La fotografia: El seu valor psicopublicitari," the camera converted a common object into something new, with great "interès publicitari." In addition to the camera's ability to expand, fragment, and surprise, he also focused attention on the photographer's ability to heighten a viewer's reaction through the use of photomontage, photograms (a camera-less image made by projecting light over objects placed on top of photographic paper), and an unlimited number of camera and darkroom tricks. In his later essay, "Tècnica de la fotografia publicitària," Català-Pic provided instructions for executing these procedures successfully. From making sure that there were no empty spaces between joined photographs in a photomontage to monitoring the quality of the paper used for a final print, the photo-technician had to be in perfect control of every aspect of the image's production. It was, indeed, the difficulty (and necessity) of controlling the photographic process that Català-Pic emphasized throughout this 1933 essay for the Butlleti: "Com es pot comprendre, no és una tècnica fàcil." 


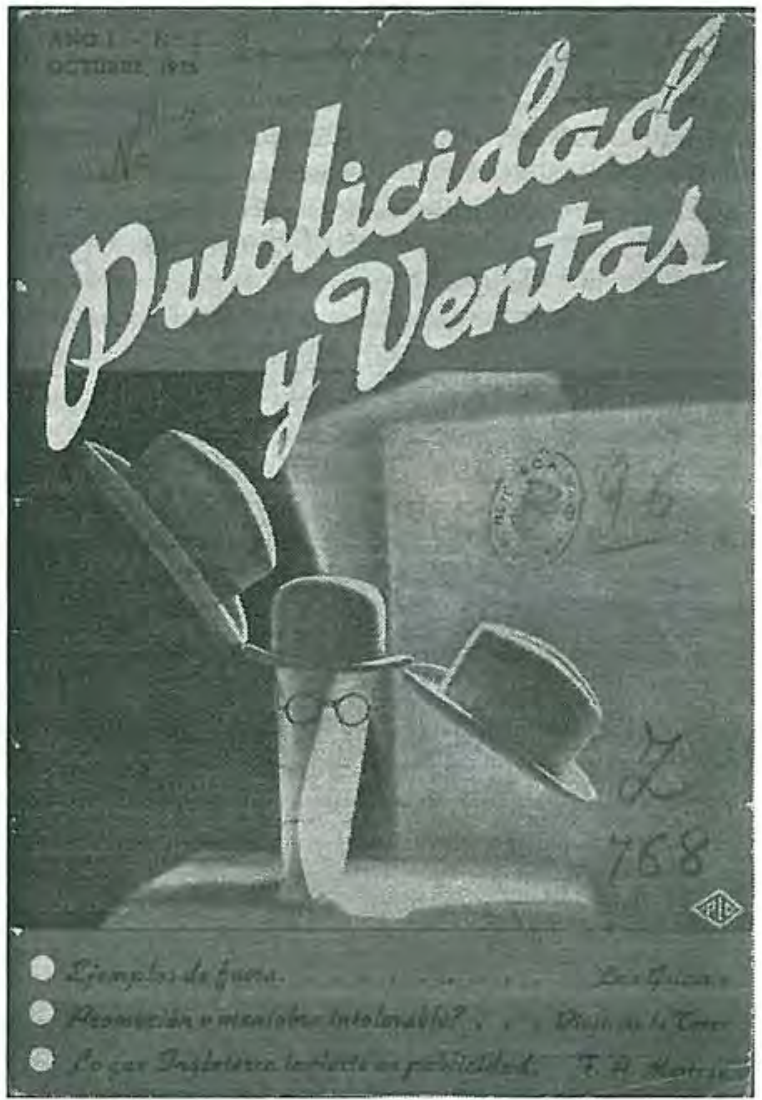

FigURA 3

MAKING MODERNITY VISIBLE: FROM D'ACI I D'ALLÀ TO NOVA IBERIA

Parallel to the development of the specialized activities of the Institute and its publications, Català-Pic was involved in popularizing the lessons learned in the Seminari. He believed that publicity was not exclusively a technical matter but also a representation of something much grander.

As he explained in his article, "La Publicitat és un element de progrés" (which appeared in Publi-Graf): "L'anunci és un signe de civilització." In other words, a rational urban culture created through 
the lessons of applied psychology and the skills of the artisttechnician was a crowning sign of modernity. Projects like PubliCinema helped to bring the city's middle-class consumers into contact with advanced ideas about culture, spectacle, and display. Distributed free of charge, the magazine featured essays by Barcelona's leading writers, including Josep Palau and Carles Soldevila. Another way that Català-Pic promoted the integration of publicity into the every day life of Catalans was through his leading role in a range of illustrated magazines, from the professionally oriented Publicidad $y$ Ventas (1935-36) to the "ladies magazine" Claror (1935-36) [Fig. 3]. Each magazine blended, albeit in different ways, art, culture, and the economy by showcasing new work by Barcelona designers, writers, and photographers (including Josep Sala, Josep Masana, and Català-Pic himself). ${ }^{3}$

Without a doubt, one of the most important illustrated magazines to bring publicity to the fore as a modern artifact was D'Aci i d'Allà $(1918-36)$, which entered its third epoch in 1932 under the artistic direction of Josep Sala, who spearheaded a remarkable make-over that included a metal spiral binding, an enlarged format, and publicity filled content. In his essay on "La fotografia i els bells magazines," written during the Civil War, Català-Pic recalled: "La publicació d'aquest magazine trimestral, tant per la seva part publicitària com pel seu contingut literari i artístic, representa un motiu de joia per a nosaltres, ja que és la primera en valor i modernitat que s'edita a la península." That D'Ací $i$ d'Allà functioned as a lasting model for the photographer in his own editorial endeavors is clear. Both Claror and Publicidad y Ventas were beautifully produced, with an artful use of typography and a generous number of photographs.

During the Civil War, Jaume Miravitlles, who had become the head of the Generalitat's Comissariat de Propaganda, named CatalàPic director of publications. One of the Comissariat's most beautiful magazines was Nova Ibèria. Three issues of the magazine appeared in multiple languages for international distribution. Like the magazines of the rg3os to which Català-Pic had contributed, Nova Ibèria showcased Barcelona's artists, writers, and designers. One of the magazine's issues included a photogram by Josep Sala, who also worked for the Comissariat during the war. Deploying one of publicity's newest and most experimental photographic methods, he transmitted a legible vision of "Els gasos de guerra $\mathrm{i}$ les indústries de pau" in an abstract photogram

3. In his book Los años de diseño, Enric Satué reminds us that Sala exhibited at the "I Saló Nacional de Fotografia Publicitària", for which Català-Pic presented his lecture "La fotografia moderna com a element de publicitat", and that Masana was the owner of space used for Publi-Cinema. 
of what appear to be pills, smoke, glass, and fabric. For Català-Pic, and for readers of Nova Ibèria, modernity and advanced artistic techniques became synonymous with the fight against fascism and the revolutionary promise of a new society.

To convey his views on the role of publicity to his readers, CatalàPic included in Nova Ibèria's first issue an essay titled "Estructuración de una nueva propaganda." His essay is one of the clearest statements to appear during the war on the relationship between commercial publicity and political propaganda. It also demonstrated the impact of the Generalitat's Institute on Català-Pic's understanding of publicity as a means to social transformation. He opened his essay with the forceful declaration: “¡Propaganda! He aquí la palabra mágica y poderosa que determina ya el éxito, ya el fracaso, no tan sólo de una marca, de un

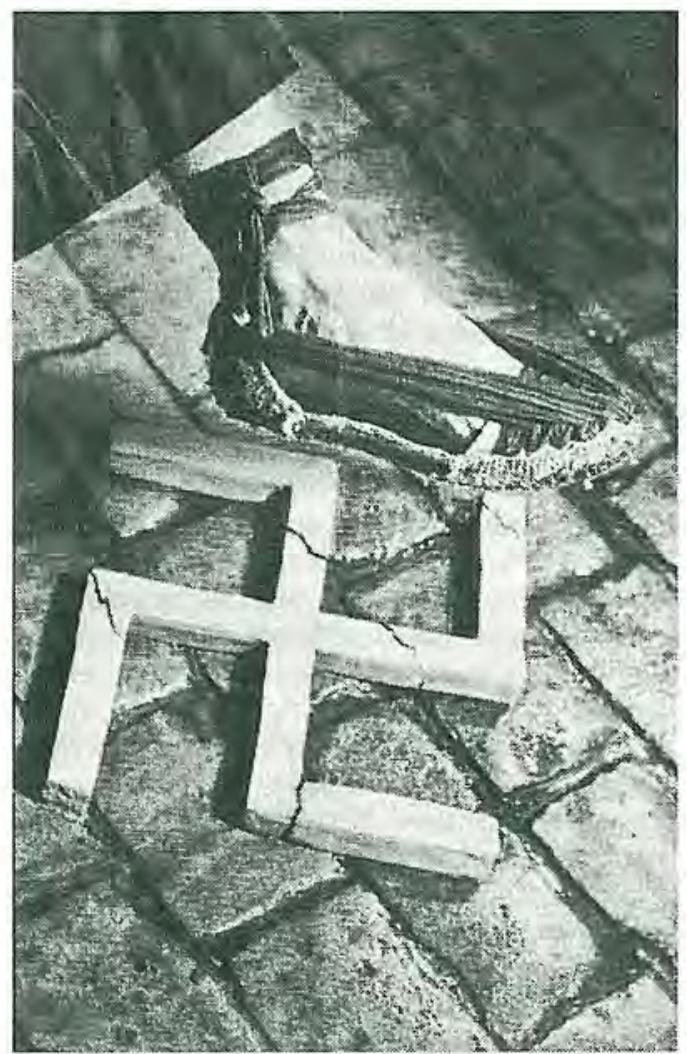

FIGURA 4 
artículo o de un prestigio, sino, también, el porvenir esplenderoso o la rápida decadencia de un movimiento político," Further emphasizing the critical importance of successful propaganda, he explained: "debemos saber, también, que un error publicitario o una oportuna estratagema pueden retrasar un éxito capaz de ahorrarnos muchas vidas humanas." Here, after the abstract theories, professional debates, and national polemics, we are treated to the full meaning and impact of the technician's role in society. Català-Pic warned that mistakes in the composition of propaganda could cost hundreds of human lives. To fight against such occurrences, he advocated, as he had throughout the 1930s, the scientific study of psychology and the appropriate use of visual techniques. He emphasized the importance of pedagogy and government sponsored programs in establishing a rational system for publicity. For him, the creation of a new sociery entailed the proper training of future "psicotécnicos." With that goal before him, he praised the establishment of the Comissariat de Propaganda by the Generalitat and the Ministerio de Propaganda by the Spanish government.

While he was working for the Comissariat, Català-Pic published articles on art and culture in the magazine Meridia (the title given to the wartime version of Mirador after the magazine was collectivized). His work as a critic along with his position at the Comissariat left him little time to compose propaganda posters, the form of visual communication most often associated with artists' participation in the Civil War. The one poster he designed for the Comissariat, titled "Aixafem el feixisme," has become one of the war's most famous and memorable visual slogans: a foot wrapped in a traditional Catalan rope-soled sandal hovers forcefully over a cracked swastika [Fig. 4]. Though not an actual photomontage, the poster resembles one in that it presents two juxtaposed images: the Nazi emblem against a backdrop of wet pavement and a defiant, extended foot. No words are needed, the message is clear: popular revolution has the power to defeat fascism. As an image, it convincingly puts the lessons of applied psychology to use (though it was obviously unable to swing the course of Spanish history.

Català-Pic was not alone in recognizing the power of propaganda during the Civil War. The hundreds of posters, pamphlets, and magazines that were published between 1936 and 1939 attest to the prominence that publicity had acquired in public life during the I930s. Other members of the Institute contributed, like Català-Pic, to the public discourse on publicity. Juan Aubeyzon published an essay ritled "Cómo conducir a la multitud" in the war-time illustrated magazine $M i$ Revista. Even more didactic than Català-Pic, Aubeyzon analyzed poster production in terms of the efficiency of its message and the clarity of its design. Both men understood, however, that the poster 
provided a visual platform for mass communication, and that such a position required the collaboration of trained artists and viewers. Both also realized that the poster, because of its size and placement, automatically called attention to itself. As Aubeyzon explained: "el medio cartelístico demuestra su poder de convicción pública: no habla, pero al leerse y verse, hace hablar y comentar su finalidad. Exige la atención de todo el mundo, aun del más absorbido en el asunto, y obra por el contagio inevitable de su pública exhibición." Here Aubeyzon presents the relation between viewer and object as one of immediate and necessary response. Unfortunately, the nature of that response and the direction of the viewer's political allegiances could not be predicted by even the most scientific of the methods used by the Institute's technicians.

Although Prat-Gaballi moved back to Barcelona in 1935, with plans to open up another advertising agency there, and although he had contributed actively to the discourse on publicity throughout the 1930s, I have not found any of his essays published during the war. After 1939, while Català-Pic struggled to find ways to continue working as a photographer and designer with the help of his sons Pere and Francesc, Prat-Gaballí published several books on publicity, including El poder de la publicidad: Nuevos ensayos (1939) and Publicidad combativa (1955), both of which addressed the political use of propaganda directly. PratGaballí developed his views distinctly from many of his colleagues, such as Català-Pic and Aubeyzon, who actively published in Barcelona's wartime publications. Despite their differences, these theoreticians shared the goal of creating a culture of publicity (Català-Pic and PratGaballí continued their correspondence well into the post-war period). Each technician contributed to the institutions and practices that marked the development of publicity during the i930s; in so doing, they helped to give a dominant role to visual culture in the creation of an economic and artistic modernity in Barcelona that fed directly into the production of political propaganda during the Civil War.

\section{JORDANA MENDELSON UNIVERSITY OF ILLINOIS, URBANA-CHAMPAIGN}

\section{WORKS CITED}

"A manera de presentación." Publi-Cinema I (October I934): I.

Aubeyzon, Juan. "Cómo conducir a la multitud." Mi Revista II: 6 (I January 1937): np.

BORI, Rafael and José GARDÓ. Manual práctico de publicidad. 2 vols. Barcelona: Editorial Cultura, 1926/1928. 
Tratado completo de publicidad y propaganda. Barcelona: José Montesó Editor, I935.

CAMPILLO, Maria. Escriptors catalans $i$ compromís antifeixista (19361939). Barcelona: Curial Edicions Catalans/Publicacions de l'Abadia de Montserrat, 1994.

CATAlÄ-PIC, Pere. "La publicitat moderna." Mirador V: 216 (23 March 1933): 7 .

—. "La publicitat moderna." Mirador V: 220 (20 April 1933): 2. - "La fotografia: El seu valor psicopublicitari." Butlleti Seminari Publicitat I: 1 (July 1933); 16-17.

—. "Un article per "Art de la Llum'." Art de Llum: Revista Fotografica de Catalunya I: 3 (August 1933), 19-20.

- "Tecnica de la fotografia publicitària." Butlleti Seminari Publicitat I: 3 (November 1933): 59-60.

—. "Per un Laboratori de Publicitat (al Dr. E. Mira)." Mirador VI: 26I (I February 1934): 7.

—. "La publicitat és un element de progrés." Publi-Graf: Portantveu de Publi-Club I (June I934): II-I2.

—. "Publicitat racional." Publi-Graf: Portantveu de Publi-Club 2 (November 1934): II-I2.

_- "Estructuració d'una nova propaganda." Nova Iberia I (January 1937), np.

—_. "La fotografia i els bells magazines." Mirador 7: 313 (I4 February 1937): 7 .

CATALA-ROCA, Francesc. Impressions d'un fotògraf. Memòries. Barcelona: Edicions 62, 1995 .

FONTCUBERTA, Joan. Idas \& Chaos: Trends in Spanish Photography 1920-1945. Madrid: Ministerio de Cultura, 1985.

FUNDACIO LA CAIXA. Les avantguardes fotogräfiques a Espanya $1925-$ 1945. Barcelona: Fundació La Caixa, 1997.

GIESE, Fritz. Psicotecria. Trans. Miguel González. Barcelona: Editorial Labor, 1933 .

PARCERISAS, Pilar. Pere Català-Pic: Fotografía y publicidad. Barcelona: Lunwerg and Fundació La Caixa, 1998.

Prat-Gaballf, Pedro. Una nueva técnica: La publicidad científica. Barcelona: Cámara de Comercia y Navegación de Barcelona, 1917.

- "Els Serveis de Psicotècnica Publicitaria de la Generalitat de Catalunya." L'Opinió 574 (April 6, 1933): 9.

—. Publicidad racional. Barcelona: Editorial Labor, 1934.

—. "Portic." Publi-Graf: Portantveu de Publi-Club i (June 1934): I.

- El poder de la publicidad: Nuevos ensayos. Barcelona: Editorial Juventud, 1939 .

_. Publicidad combativa. Barcelona: Editorial Labor, 1955. 
SAIZ, Dolors and Mílagros SÁZz. "El Seminari de Publicitat del Institut Psicotècnic de la Generalitat." Revista de Historia de la Psicologia 19: 2-3 (1998): 225-34.

SATUE, Enric, Los años de diseño. La década republicana Ig3r-1939. Madrid: Turner, 2003.

- El diseño gráfico en España. Historia de una forma comunicativa nueva. Madrid: Alianza Editorial, 1997. 